\title{
Social Performance of Indonesia Islamic Banking: Analysis of Islamic Social Reporting Index
}

\author{
Resa Saridona \\ Faculty of Economics and Business, PadjadjaranUniversity \\ Jalan Dipati Ukur 35 Bandung \\ resa.saridona@gmail.com
}

\author{
Martha Fani Cahyandito \\ Faculty of Economics and Business, Padjadjaran University \\ Jalan Dipati Ukur 35 Bandung \\ cahyandito@yahoo.com
}

\begin{abstract}
Banking plays a vital role as the world's economic driver in a country, including Islamic bank, which is now thriving rapidly. However, it could not be denied that there are social and environment impacts which are caused by Islamic bank. The study aims to explore the social and environment performance of Islamic Bank in Indonesia by using Islamic Social Reporting Index. The data analysis used in this study is quantitative content analysis against overall population of Islamic bank in Indonesia. The resource of data is the annual report of Indonesia Islamic banks of the 2013 period.

The analysis result shows that, in general, social performance of Indonesia Islamic banks, which is revealed in the 2013 annual reports, is in 'good' category (statistically fulfilled $61.73 \%$ of the overall social performance index). From the whole population of Islamic banks in Indonesia, the Bank Syariah Mandiri (BSM) is acknowledged with the highest rank using the Islamic Social Reporting Index. Meanwhile, the Islamic Victoria Bank is listed in the last rank with adequate predicate. The stateowned enterprise banks have better social performance, followed by Bank Muamalat Indonesia, as the pioneer of Islamic Bank in Indonesia.

In general, CSR activities are conducted by Islamic Banks in Indonesia, which focus on social activities, including the aid for privilege community, educational program such as the improvement of educational tools, and also the health care. Unfortunately, there are still few of Islamic Banks who have the concern to the conservation of environment.
\end{abstract}

Keywords---Social and Environmental Performance; Islamic Reporting Index; Indonesia IslamicBanking

\section{INTRODUCTION}

Social performance or more often refers to Corporate Social Responsibility (CSR) is no longer a new concept in business activities. The big company such as Sido Muncul, Unilever, Aqua, Telkom have inspired many other companies by their innovative CSR activities (Lako, 2010). These companies prepare lots of funds for CSR activities. CSR funds, theoretically and practically, has a great potential in helping reducing poverty in Indonesia if it is managed properly.

In the beginning, the practice of the implementation of CSR reporting in Indonesia was dominated by go-public companies in the mining or manufacturing sector; and followed by banking sector (Fitria and Hartanti, 2010). This is because the banking sector has good growth and became one of the three auctions that can support the growth rate of the composite stock price index (IHSG). As expressed by the Association of Indonesia Securities Analysts (AAEI, 2015), the leading stock sectors that can sustain growth by 2015 is the JCI stake in construction, infrastructure, banking and also Islamic banking. The growth of Islamic banking is above 30\% per year. It is higher than conventional banking growth even though the market share of the Islamic banking is still below $5 \%$.

The implementation of CSR in the Islamic banking is very relevant to evaluate because the nature and operation of Islamic Banking is based on the values of Islam. Social performance is endorsed for Islamic banking. Islamic banking has to be responsible since it becomes one of the distinctive features of Islamic banking which help to increase the life quality of society through mechanisms that are not contrary to the laws of Islam.

However, nowadays, the CSR activities of Islamic banking has not yet performed well. This is according to the research conducted by several researchers. Sofyani, et. al. (2012) conducted a study with the title of Islamic Social Reporting Index as a Model of Social Performance Measurement of Islamic Banking (comparison study between islamic banking in Indonesia and Malaysia) using annual report for the period of 2009 and 2010. In general, the results of this study found out that the performance of islamic banks in Indonesia and Malaysia has not yet reached full disclosure score of Islamic Social Reporting Index (ISR). The performance level of Islamic Banking in Malaysia are higher than the social performance of Islamic banking in Indonesia.

The similar study was also carried out by Azhar and Rina (2013) concerning the disclosure of Islamic Social Reporting on five Islamic Banking in Indonesia using ISR index. The result was that the average score of Islamic Social Reporting index was approximately $48.75 \%$ (still below $50 \%$ ). This indicated that Islamic banking has not yet carried out and reported (fully disclose) its social function to the public. Further research was also done by Fitria Hartanti (2010) and the results of the research was that the CSR implementation in 
Conventional Banking is better than the Islamic banking. According to Farook and Lanis, as quoted by Muhammad (2007), recently studies indicate that Islamic banking has not yet formally performed well in implementing its social functions in accordance with Islamic values.

This indicated that Islamic banking is still not carrying out its social function optimally. But since the establishment of Islamic banking in Indonesia with a marked the establishment of Bank Muamalat Indonesia (BMI) on November 1, 1991 one of the function and its role is to carry out social functions in order to help people prosperity. Act No. 21 of 2008 about Islamic banking article 4 points 2 mentions that one of the functions of the Islamic banks and Sharia Business Units (UUS) are doing a social function in the form of Islamic Treasury, i.e. institutions receive funds originating from zakat, alms, infak, grants, or other social funds and channel it to the organization who manages the zakat. As well as the opening of the accounting standards issued by AAOIFI (Accounting and Auditing Organization for Islamic Financial Institution), one of the functions and the role of Islamic banks, namely the implementation of a social activity, is as a distinctive entity attached to Islamic finance, Islamic banking also has a duty to issue and manage the funds (spool, administrating, distribute) zakat and other social funds. In more detail, Suharto, et al. (2001) in Setiawan (2009) describes the functions and the role of Islamic banks, are as follows: (1) an investment manager that manages the investment of customer funds by using the mudharabah contract or as an investment agent; (2) investors who invest the fund assets as well as customer funds entrusted to him by using the appropriate investment tools with sharia principles and share the results obtained in accordance with an agreed ratio between the bank and the owner of the funds; (3) financial service provider and payment traffic as a non bank syariah along does not conflict with Islamic principles; and (4) Establishing social functions in the form of a Fund Manager religious obligatory, infaq, sadaqah as well as the loan of virtue (qard Al-hasan) in appropriate conditions. According to explanation above, it is very apparent that first function up to third is related to business functions, and the functions of the social role from the Fourth function of Islamic bank. It is also expressed by Wiroso (2009) which divided four Islamic banks function as follows : the main function of the functions of the investment manager, a function of investors, banking services, functions and social functions.

Antonio (2001) in Setiawan (2009) added about Islamic banking function. In addition, to have the function as investment manager and provider of financial services, includes social services. In his view, the concept of Islamic banking requires Islamic banks should carry out social services, through loan funds goodness (qard), zakat, or the Social Fund based on the principle of Islam. Furthermore, according to him the concept of Islamic banking also requires Islamic bank plays a role in the development of human resources and contributes funds for the maintenance and concervation of the environment.
In addition, as a social function inherent in Islamic banking, the aim of Islamic banking related to CSR is to solve the poverty problem. Generally, the placed as the main program of the developing countries. Islamic banks effort in solving the poverty problem is implemented by coaching clients a more understated nature of the business cycle from being complete as the manufacturer, entrepreneur, coaching intermediary traders, consumer, labor and capital development program development program joint venture (Abdurahman, Isa. 1996 in Sudarsono, h. 2008).

Hendry Astuti (2008) and in Gustani (2013) stated that social functions will be attached to inhern on Sharia as a consequence of business institution by their reliance on Islamic institutions in Islamic values. The institution of Sharia business cannot be separated in dichotomous between its business orientation with social orientation or at least are not contradictory. This is in line with what was expressed in the research of Sukma (2013) that Islamic banking is not purely functional and business-oriented (business oriented). However, there is a social function which should be executed.

Therefore, the background of Islamic banking to implement CSR community prosper is in order and improves environmental quality as the implementation of a transparent business practices and responsible, positive image building, building a good reputation, and increases public awareness about Islamic banking through social activities. Next, as the efforts of Islamic entity in achieving long-term sustainability, sustainablity business means not only seeks to maximize economic performance to the shareholders, but also thoroughly tries to give maximum contribution to the social and environmental aspects, realizes the society fairness and prosperous in line with the basic principles of Islamic economy, gets the government support and guidelines, and regulations that strengthened the Islamic banking.

Since CSR issues exposed and became world trends, many researchs related to CSR measured the factorthat CSR disclosure aspects influenced Islamic banks as well as to the level of the social performance of Islamic banks. However, there is still no standard raw disclosure and corporate social performance measurement until today (Gustani, 2013). Islamic banks are still based on conventional standards, namely the global reporting index (GRI) (Haniffa, 2002. Nany N 2012). Whereas in the GRI indicators that there has not been adequate if it is used for business institutions of Islam, and even for the core of Islamic banks namely disclosure regarding the lack of activity of usury, gharar, zakat, and other Islamic values thus not found in item GRI. Inexistence of a standard index for measuring the performance of Islamic banks prompted Haniffa (2002) for observing and developing indicators that can be used to measure the level of disclosure and performance of Islamic banks called as Islamic Social Reporting (ISR) index. Index of ISR include items contains a compilation of all the Stakeholders expectations of Islamic banks which is not only for human beings but also the main stakeholders, namely the Almighty God, Allah SWT. This index was an adaptation of the ISR AAOIFI (Accounting and Auditing Organization For Islamic Financial Institusion). Research conducted by Haniffa 
encourages other researchers to observe similar topics like Othman and Thani (2010), which adds one new theme in the ISR index.

ISR existence might measure the social performance in the public Sharia banks as long as it is not accommodated by the CSR implementation guideline conventional indicators, especially in such a spiritual business freedom activity of usury, gharar, presence of zakat, and others. Therefore, by using ISR index, Islamic banks, it is possible to get a social performance information which is more relevant and accurate.

The important of social performance measurement conducted by Islamic banking as a means of evaluation of the effectiveness of a CSR programs from each Islamic bank, is fulfilling the principle of transparency, as motivation to remain consistent (istiqomah) and to compete in the goodness (fastabiqul khairot) with the intention of correcting the willingness in order to serve God. In addition, the expectation of implementation of the social performance of Islamic banks is to be a role model for other companies.

\section{a. Research Question and Goal}

The research question in this research is how is the social performance of Islamic banking in Indonesia which is disclosed in the annual report of the 2013 by using Islamic Social Reporting Index. The purpose of this research is to explore the social performance of Islamic banking in Indonesia which is disclosed in the annual report of the 2013 by using Islamic Social Reporting Index.

\section{b. Research Use}

The results of this research are expected to provide scientific insight as a portrait of the social performance of each Islamic bank in Indonesia to become material input for decision makers in developing the social and environmental program for Islamic banking so that they can function as they should be, according to the rule of religion and as demanded by the stakeholders.

\section{LITERATURE REVIEW}

Social performance is related to the results achieved by the company for its concern and social field. Social performance is means refer to the implementation of corporate social responsibility (CSR). Then, according to the World Business Council for Sustainable Development (1999) CSR is a commitment of business to contribute sustainable economic development, work with employees of the company, the employee's family, following the local communities and the community as a whole in order to improve the quality of life. The term commitment is also expressed by Putri (2007) in Untung (2008) defines CSR as a corporate or business world's commitment to contribute the development of a sustainable economy by looking at the corporate and social responsibility, focuses on the balance between concern for economic, social aspects and the environment.

The Law No. 40 Year 2007 uses the term CSR in defining commitment. Social and environmental responsibility is a commitment of the company to participate in sustainable economic development in order to improve the quality of life and the beneficial of environtment, both for the company itself, the local community, or society in General. Commitment means a strong desire followed by consistent maximum effort.

Thus, it can be concluded that CSR is a commitment of the company to implement its obligations towards stakeholders as well as play a role in improving the quality of life of the local community and environmental sustainability. Since the 1970s up to the present, it has occurred 12 times in the evolution of the theory of the concept of CSR is (Krisnawati 2014, et al). There are many benefits of CSR implementation in the long term one is increasing the value of the company.

In contrast to Western theory, CSR is relative and depends on the needs of implementation reasons without any solid foundations. Islam puts a holistic approach to CSR (Dusuki, 2008) as an intergrated part of one's spiritual, therefore the implementation of CSR must be meant as an attempt to grab the let. In addition the concept of CSR is closely to the goals of human existence on Earth to worship and became Caliph in the Earth.

ISR Index is an extension of social reporting which ont only includes society's expectations regarding the company's role in the economy, but also the role of the company in a spiritual perspective (Haniffa 2002 in Azhar and Rina 2013). ISR Index is the benchmark in implementing Islamic Banking in social responsibility which contains a compilation of CSR standard items specified by AAOIFI (Accounting and Auditing Organization for Islamic Financial Institutions) which was then further developed by researchers about CSR items which should have been disclosed by an Islamic entity. To its Development Index ISR developed by Othman and Thani (2010) consists of six theme which are funding and investment theme, the second, is product and service theme, the third, is employee theme, the fourth is the society theme, the fifth is the Environment theme and the last is Good governance theme. Each theme was revealed to be a more specific item so total item of ISR index was 43 items.

\section{RESEARCH METHOD}

Quantitative content analysis method was used in this research. It is a technique of scientific research that aims at identifying the communication content which looks systematically (manifest). It is conducted in an objective research, validity, reliability, and also can be replicated. This study uses secondary data which are the annual report period 2013 of each Islamic bank. The determination the object of research by means of the Census because of the population of Islamic banks is still below 20 banks.

Data analysis was done by giving the score of $0-1$, if :

- The score " 0 " is applied if there is no disclosure on the item of ISR absolutely

- The score "1" is applied if there is a disclosure on the item of ISR and expressed clearly. 
If all of the item ISR Index disclosed in the annual report of Islamic Bank so it means that the Islamic Bank will get full score which are 43 points. After scoring process of ISR Index finished to each Islamic Bank, the analysis will be do in order to know each of its social performance. After that, it will be calculated the average for each item. Social performance disclosure index calculation is formulated as follows:

ISR index $=$ The number of items disclosed $\times 100 \%$ The total number of items

According to research was done by Rahma (2012), in this research was also equipped with an interval scale of measurement index in order to determine its social performance predicate. the interval scale used as follows.

Table 1. The interval scale of social performance predicate

\begin{tabular}{|c|c|}
\hline Number of Percentage & Predicate \\
\hline $80,20 \%-100,00 \%$ & Very good \\
\hline $60,40 \%-80,20 \%$ & Good \\
\hline $40,60 \%-60,40 \%$ & Adequate \\
\hline $20,80 \%-40,60 \%$ & Bad \\
\hline $1,00 \%-20,80 \%$ & Very bad \\
\hline
\end{tabular}

Source: Rahma, N (2012)

The scores of ISR Index was interpreted so that it reflects its social performance condition of Islamic Banking.

\section{RESULTS AND DISCUSSION}

The cumulative percentage of social performance using Index ISR each Islamic bank in Indonesia could be seen in the picture 1 below.

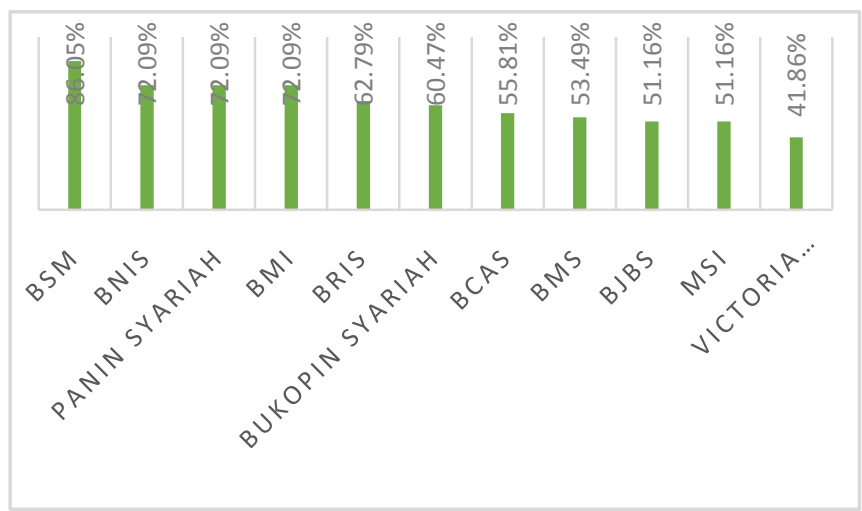

Picture 1. The Social Performance of each Islamic Bank Source: Secondary data, Processed by the researcher (2015)

From the Picture 1, it could be seen that Bank Syariah Mandiri gets a percentage of $86,05 \%$ or as much as 37 items disclosed tops the list in terms of implementation of CSR at once strict confidence, using an index of ISR in annual report of 2013. While it is the last position occupied by Victoria Bank Syariah.The second position is occupied by three public syariah bank, i.e. BNI Syariah, Bank Panin
Syariah, and Bank Muamalat Indonesia, with the percentage of $72,09 \%$.

Table 2. Social Performance Predicate of Islamic Bank

\begin{tabular}{|c|l|c|}
\hline No & \multicolumn{1}{|c|}{ Names of Islamic Bank } & $\begin{array}{c}\text { Social } \\
\text { Performance } \\
\text { Predicate }\end{array}$ \\
\hline 1 & Bank Syariah Mandiri & Very Good \\
\hline 2 & $\begin{array}{l}\text { Bank Negara Indonesia } \\
\text { Syariah }\end{array}$ & Good \\
\hline 3 & Bank Panin Syariah & Good \\
\hline 4 & Bank Muamalat Indonesia & Good \\
\hline 5 & $\begin{array}{l}\text { Bank Rakyat Indonesia } \\
\text { Syariah }\end{array}$ & Good \\
\hline 6 & Bank Bukopin Syariah & Adequate \\
\hline 7 & Bank Central Asia Syariah & Adequate \\
\hline 8 & Bank Mega Syariah & Adequate \\
\hline 9 & Bank Jabar Banten Syariah & Adequate \\
\hline 10 & $\begin{array}{l}\text { Bank Maybank Syariah } \\
\text { Indonesia }\end{array}$ & Adequate \\
\hline 11 & Bank Victoria Syariah & Sear \\
\hline
\end{tabular}

Source: Secondary data, Processed by the researchers (2015)

However, in general, there are no Islamic bank in Indonesia who fully $(100 \%)$ use index ISR to carry out their social activities. This happens because of the first two possibilities. The first is that because the Islamic bank does not implement CSR activities such as education about the environment or policies regarding green banking. Green banking is understood at the moment only as greening the bank building. Green banking is actually channeling the financing provided to companies engaged in the sector which does not damage the environment and the social condition of society.

Green banking is not only talking about the physical appearance of the bank as the shape of the building, or the program environmentalgreening/maintenance conducted by the bank. There should be a policy of the bank to perform filtering in the financing process for banks to apply the concept of green banking. The second reason, is that the Islamic banks which carry out CSR activities, do not disclose their performances in the annual report. The average of social performance throughout the Islamic banks in Indonesia is $61,73 \%$ (in 'good' predicate). However, this figure is still far from the expections of stakeholders who expect percentage rate of $100 \%$.

From the results of research, there are four items that are absolutely not disclosed by the public bank syariah in Indonesia. There are as follows: disclosure of items or no activity in Islamic banks, gharar policy bank employee groups in need of special such as persons with disability, ex-convicts or ex-drug addict (the employment of other special-interestgroup i.e. handicapped, ex-convict, former drug addicts.), policy implementation of the prayer in congregation with the lower level manager or any medium (higher echelons in the company perform the congregational prayers with lower and middle level managers), as well as policies relating to the 
bank's attention against the nearly extinct animals (endangered wildlife).

Whereas the fourth item above which were not disclosed by the public bank Sharia is very important. For example, regarding employment opportunities at the company for people with disability have been mandated by law No. 4 of 1997 article 13 stating that every disabled person has in common with the opportunity to get the job done in accordance with the type and degree of the defect but conventional banks like Bank already implemented the mandate of ACT No. 4 of 1997 on this. Then pray in Congregation is the implementation of the fundamental things that ought to be disclosed by public Islamic Bank. There are many benefits from the implementation of this congregation prayers. In addition, there is also a lesson about the concept of leadership in congregation prayers to get a great reward from Allah almighty.

In general the items in the index are relevant as ISR guidelines implementation, disclosure and social performance measurement. However, there are a few more will be recognized again if the authorities to apply the index to the Global ISR Reporting Initiative (GRI) index for ISR totally unnoticed by the rest of Islamic banks in the world and become the public islamic bank standard in carrying out its social activities and measures.

\section{CONCLUSION}

Based on the results of the research, it could be concluded that:

Overall social performance of Islamic banks in Indonesia is disclosed in the annual report of $61,73 \%$ in 2013. This percentage included the range of predicate, but this percentage had lower limit and was still far from the expectations of the Stakeholders. Expected numbers in a percentage of social performance reached $100 \%$.

from the whole of Indonesia Islamic banks, it is only one Islamic bank who gets the very good predicate i.e. the social performance of Syariah Bank Mandiri (BSM). Meanwhile, Bank Syariah Victoria was ranked last with adequate predicate. Social performance with either more occupied by state-owned enterprises (BUMN) followed by Bank Muamalat Indonesia as a pioneer.

In general, the focus of Islamic banks CSR activities is the social activity, it is still a little bit of Islamic bank that cares about the environment, education, as well as a health aid. Still a bit of public bank syariah who have a concern against the maintenance of the environment.

The items in the index are relevant to the measurement of ISR and social performance disclosure. It's just that there were no items of community empowerment as well as items employee spiritual improvement program such as mentoring (coaching). Yet any specific explanation in item employee involvement whether it is related to the concept of management by shura Council (consultative) or not. Lastly, there are items about graduate employment in the community, it become difficult to be interpreted when placed in the theme of society and would be more relevant if placed in the theme of employees.

\section{VI.RECOMMENDATION}

The recommendation of this study are as follows:

For Islamic Bank in order to continue improving the understanding of social functions with training to employee and always in such a religious activity in chart study routine or even every morning briefing. Reporting on CSR activities is very important to be reported in annual reports, websites and more interactive means such as social media.

For regulators who set up Islamic banking in Indonesia in order to quickly create and apply for the manufacture of standard implementation, disclosure of social performance measurement as well as for public bank syariah should be recognized internationally as the Global Reporting Initiative to filing (GRI) to all syariah bank in Indonesia not to use again the guidelines implementation and measurement of CSR activities of conventional.

For the next interested researchers to examine social performance using index of ISR should conduct in-depth study on items existing ISR, connecting with social performance measurement tool like other ethical ideal Islamic identity, as well as social performance research using primary data sources with the case study approach to measure the social performance in a more profound and comprehensive.

\section{REFERENCES}

[1] Al-Qaradhawi, Yusuf. 2001. Islam Agama Ramah Lingkungan. Diterjemahkan oleh Abdullah Hakam Syah, Dkk. Jakarta : Pustaka Al-Kautsar.

[2] Antonio, Muhammad Syafi'i.2001.Bank Syariah dari Teori ke Praktik. Jakarta : Gema Insani Press.

[3] Azhar, Fahri Ali, Rina Trisnawati, et al.2013. Pengungkapan Islamic Social Reporting pada Bank Syariah di Indonesia, page 477-483.

[4] Dahlsrud, A. 2006. How Corporate Social Responsibility is Defined: an Analysis of 37 Definitions [Online]. http://onlinelibrary.wiley.com/doi/10.1002/csr.132/pdf (accessed on December $15^{\text {th }}$ 2014).

[5] Eriyanto.2013.Analisis Isi. Jakarta : Kencana Prenada Media Group.

[6] Fitria, S., dan Hartanti, D. 2010. Islam dan Tanggung Jawab Social: Studi Perbandingan Pengungkapan Berdasarkan Global Reporting Initiative Indeks dan Islamic Social Reporting Indeks. Purwokerto: SNA XIII.

[6] Gustani. 2013. Analisis Tingkat Pengungkapan Kinerja Sosial Bank Syariah Berdasarkan Islamic Social Reporting Index (Indeks ISR). Skripsi.Jakarta: STEI SEBI.

[7] Haniffa, R. 2002. Social Reporting Disclosure: An Islamic Perspective. Indonesia Management \& Accounting Research, 3, page 128-146.

[8] Kamus Besar Bahasa Indonesia [Online]. 2015. http://kbbi.web.id/ (accessed on February 17 $7^{\text {th }} 2015$ ). 
[9] Karim, Adiwarman A. 2008. Bank Islam Analisis Fiqih dan Keuangan.Jakarta: PT RajaGrafindo Persada.

[10] Krisnawati, A et al. 2014. Development Path of Corporate Social Responsibility Theories. World Applied Sciences Journal 30 (Innovation Challenges in Multidiciplinary Research \& Practice): 110-120, 2014. ISSN 1818-4952.

[11] Lako, Andreas. 2010. Dekontruksi CSR \& Reformasi Paradigma Bisnis \& Akuntansi. Jakarta : Erlangga.

[12] Othman, R., \& Thani, A. M. (2010) Islamic Social Reporting of Listed Companies in Malaysia.International Business \& Economic Research Journal , 3, page. 135144.

[13] Perwataatmadja, Karnaen A and Hendri Tanjung (2007) Bank Syariah (Teori, Praktik dan Peranannya). Jakarta: Celestial Publishing.

[14] Platonova, Elena (2013) Corporate Social Responsibility from an Islamic Moral Economy Perspective : A Literature Survey. Afro Eurasian Studies, Vol.2 page $.272-297$

[15] Putri, Sukma Fitria.2013. Faktor-Faktor yang Mempengaruhi Pengungkapan Corporate Social Responsibility pada Perbankan Syariah di Indonesia (Penelitian pada Bank Umum Syariah Tahun 2010-2012). Tesis. Bandung : program Magister Ilmu Ekonomi Universitas Padjadjaran.

[16] PT. Bank Central Asia Syariah (t.thn). Laporan Tahunan Periode 2013. Sucessfully accessed on January $17^{\text {th }} 2015$ from www.bcasyariah.co.id

[17] PT. Bank Jabar Banten Syariah (t.thn). Laporan Tahunan Periode 2013. Sucessfully accessed on January $17^{\text {th }} 2015$ from www.bjbsyariah.co.id

18] PT. Bank Mega Syariah Indonesia. (t.thn.). Laporan Tahunan Periode 2013. Accessed on January $17^{\text {th }} 2015$, from www.bsmi.co.id

[19] PT. Bank Muamalat Indonesia. (t.thn.). Laporan Tahunan Periode 2013. Accessed on January $17^{\text {th }} 2015$ from www.muamalatbank.com

[20] PT Bank Negara Indonesia Syariah (t.thn). Laporan Tahunan Periode 2013. Accessed on January 17th 2015 from www.bnisyariah.co.id

[21] PT. Bank Panin Syariah. (t.thn). Laporan Tahunan Periode 2013. Accessed on January 17th 2015 from www.paninsyariah.co.id.

[22] PT. Bank Rakyat Indonesia Syariah. (t.thn.). Laporan Tahunan Periode 2009-2011. Accessed on January 17th 2015 from www.brisyariah.co.id

[23] PT. Bank Syariah Bukopin. (t.thn.). Laporan Tahunan Periode 2009-2011. Accessed on January 17th 2015 fromwww.syariahbukopin.co.id

[24] PT. Bank Syariah Mandiri. (t.thn.). Laporan Tahunan Periode 2009-2011. Accessed on January 17th 2015 from www.syariahmandiri.co.id

[25] PT. Bank Victoria Syariah (t.thn). Laporan Tahunan Periode 2013. Accessed on January 17th 2015 from www.bankvictoriasyariah.co.id
[26] PT Maybank Syariah Indonesia (t.thn). Laporan Tahunan Periode 2013. Accessed on January 17th 2015 from www.maybanksyariah.co.id

[26] Rufaidah, Popy. 2013. Manajemen Strategik. Bandung : Humaniora.

[27] Rahma, Nadia. 2012. Analisis Penerapan Islamic Social Reporting Index dalam Pengungkapan Corporate Social Responsibility Perbankan Syariah Indonesia. Skripsi. Yogyakarta : Universitas Islam Negeri Sunan Kalijaga.

[28] Setiawan, A. B. 2009. Analisis Kesehatan Financial dan Kinerja Sosial Bank Syariah di Indonesia. Tesis tidak dipublikasi. Jakarta: Program Magister Bisnis \& Keuangan Islam Universitas Paramadina.

[29] Sofyani, H., Ulum, I., Syam, D., \& Wahyuni, S. (2012). Islamic Social Reporting Sebagai Model Pengukuran Kinerja Sosial Perbankan Syariah (Studi Komparasi Indonesia dan Melayu). JDA, Vol. 4 No. 1, page 36-46.

[30] Sudarsono, Heri. 2007.Bank \& Lembaga Keuangan Syariah Deskripsi dan Ilustrasi. Yogyakarta : Ekonisia.

[31] Sule, Ernie T., \& Kurniawan Saefullah. (2008) Pengantar Manajemen ed. 1. Kencana Prenada Media Group: Jakarta

[32] Undang-Undang No. 40 Tahun 2007 tentang Perseroan Terbatas. Accessed on December $1^{\text {st }} 2014$ fromhttp://www.hukumonline.com/pusatdata/downloadfil e/f152313/parent/26940.

[33] Undang-Undang Republik Indonesia Nomor 21 Tahun 2008 Tentang Perbankan Syariah.(2008). Accessed on December $\quad 1^{\text {st }} 2014$ from http://www.bi.go.id/NR/rdonlyres/248300B4-6CF94DF5-A6740073B0A6168A/14396/UU_21_08_Syariah.pdf 
